\title{
Analysis of Cavities Characteristics in the Semar - Kiskendo Caves System, Jonggrangan Karst Area, Kulon Progo, Indonesia
}

\author{
Romza Fauzan Agniy ${ }^{1,2}{ }^{*}$, Risma Sari Septianingrum ${ }^{3}$, Ariel Seto Adinugraha ${ }^{3}$, Qodri Alghozali ${ }^{3}$, Bagas Aditya $^{3}$, Ahmad \\ Cahyadi $^{1,3}$, Tjahyo Nugroho Adji ${ }^{1,3}$ \\ ${ }^{1}$ Karst Research Group, Faculty of Geography, Gadjah Mada University, Indonesia \\ ${ }^{2}$ Master Program on Planning and Management of Coastal Areas and Watershed, Faculty of Geography, Gadjah Mada University, \\ Indonesia \\ ${ }^{3}$ Department of Environmental Geography, Faculty of Geography, Gadjah Mada University, Indonesia
}

\begin{abstract}
The Kiskendo Cave System is a system that has many benefits, including as a tourist site and water source. One of the systems in the upstream of Kiskendo Cave is the Semar-Kiskendo Caves system. This system is estimated to greatly affect the condition of the Kiskendo cave system because it is connected to the allogenic river which contributes to recharge from outside Jonggrangan Karst Area. The purpose of this research was 1) to find out the characteristics of the Semar Cave cavities and 2) to analyze the connectivity and characteristics of cavities in the Semar - Kiskendo Caves system. This research employed a survey method by mapping the cave to answer the first problem and conducting a tracer test of underground river stream to answer the second problem. The results showed that the Semar Cave cavity that could be mapped was 158.2 meters long, the total volume of the cave was $1,220.6 \mathrm{~m}^{3}$, and the average diameter of the cave cavity was 2.8 meters. The results of second study using the tracer test showed the connection between Semar Cave and the underground river in Kiskendo Cave, and the cavities had a characteristic of a single conduit which was sufficiently developed.
\end{abstract}

Keywords: Jonggrangan Karst Area; Kiskendo; Cave Mapping; Tracer Test

\section{Introduction}

Karst area is a landscape that has unique landform and hydrological condition due to the process of dissolving rocks by water [1]. Some of the geomorphological uniqueness is characterized by the formations of doline, karst hills, sinkholes, caves, and underground rivers. Hydrologically, karst area is characterized by a lack of river at the surface and more influenced by the underground river system [2]. The karst landscape is a landscape that is formed from soluble rocks such as limestone, dolomite, gypsum and rock salt and is located in areas with high rainfall that the dissolution process takes place intensively $[3,4]$.

Underground river is one of the characteristics of karst area. This formation is taken place because of the dissolution process which begins with the appearance of caves. The caves formed in karst area that are interconnected will form a cave system and when the system is filled with water, this formation is called an underground river [5]. Cave is defined as a formation found in soluble rocks with a hole diameter that allows humans to be able to enter it [6].

Large underground river channels allow mapping with exploration [7]. However, there are often cave cavities or underground river with either very narrow or full of water that causes direct mapping is very difficult to conduct $[8,9]$. In this case, a tracer test method can be taken to determine the connectivity between caves or underground rivers and to determine the cavity characteristics formed in the underground river system [10,11].

Jonggrangan Karst Area, located in Kulon Progo Regency, Special Region of Yogyakarta, Indonesia is one of the areas that have a significant role in providing clean water. Springs in the area has supplied a large amount of clean water and has supported the tourism industry as well as agriculture, especially for rice fields. One of the large springs in the Jonggrangan Karst Area is Sumitro Springs which is a resurgence of the Kiskendo underground river. Research regarding the Kiskendo underground river system has an important role, however, only a few empirical studies related to have been done by far, especially in relation to its infiltration area. One area that is estimated to be a recharge area of the Kiskendo underground river system is the Semar Cave system. This research aims to 1) determine the characteristics of the Semar Cave cavities and 2) to analyze the connectivity and characteristics of the cavities in the Semar - Kiskendo Caves system.

Touristic activities in karst landform are frequently associated with uncontrolled waste and sewage disposal from single refuges, tourist lodges, and hotels. Therefore, rapid transport of dissolved contaminants

* Corresponding author: romza.fauzan@gmail.com 
along conduit and fractures takes place. A pollutant can migrate underground also from diffuse shallow sources, which is becoming more and more important to tourism in combination with individual touristic activities [12].

\section{Methodology}

The method used in this research was a survey which was divided into 3 stages, namely the pre-field stage, the field stage, and the post-field stage. The pre-field stage involved collecting secondary data from previous research. The field stage was cave mapping and tracer test. The post-field stage consisted of processing data obtained in the pre-field and field stages previously.

\section{Cave Mapping}

The process of cave mapping began with determining the survey points. These survey points were called as stations. Stations can be divided into 2 categories, namely fixed station and floating station [13]. The survey system in data collection used top to bottom, mapping started from the cave mouth and continued to the end of cave cavities. The method of data collection was Forward Method with the tool reader and note-taker at the back, while the stationer was in the front. Determination of station locations was based on these considerations: changes in direction, extreme changes in the cavity curve shape ( 3 dimensions), downwards, roof falls, changes in wall width, measurement limits $(30 \mathrm{~m})$, extreme elevation changes (pitch, climb), other important findings such as specific ornaments and lithology.

\section{Tracer Test}

The first step before carrying out underground river tracing was conducting a field survey by mapping the distribution of locations of cave entrance, ponor, sinking streams and springs. The tracer substance was poured in Semar Cave which was estimated to lead to Kiskendo Cave by considering the input-output of the water discharge and higher elevation of Kiskendo Cave.

The tracer test is the right method for investigating the origin, movement, and estuary of underground river. In the field of hydrogeology, tracing can be done with eco-friendly, easily recognized and easily detected materials in low concentration. Two types of tracer materials often used are fluorescent dyes and salts [14]. In this research, uranine was used as one type of fluorescents.

One of the applications of this tracer test is to validate groundwater vulnerability. For the purpose of validation, the results of the vulnerability analysis were analyzed by rainfall data, discharge data, and water quality. In principle, the analysis is to determine changes in spring discharge and underground rivers and their quality of water against rain, which in this case uses electrical conductivity, temperature, turbidity, TDS, and major elements [15].

a). Analysis of rainfall data - flow rate data, this analysis was carried out by matching the thickness of the rain (hours, daily, monthly) with variations in flow rates on springs and cave stream, so that the response of the discharge (fast-slow) to rain. b) Correlation and regression analysis between water level data and measured discharge both springs and cave stream to create stage discharge rating curves, and between water quality and spring and cave stream discharge.

c). Hydrograph analysis. Hydrograph analysis made is a water level hydrograph, a hydrograph discharge throughout the measurement year. This flow hydrograph is then used for discharge analysis of rain, knowing flow characteristics especially time to peak and run off volume.

d). Chemograph analysis. To find out variations in water quality throughout the measurement period is associated with the incidence of rain, flowrate so that it can be seen the response of water quality to rain. With the assumption that rain is a pollutant transpiration medium, then on the basis of the response of water quality to rain, it will be known that the slow travel time of water (pollutants) in springs and cave stream.

e). Tracer test. To determine the speed of travel of tracer substances in the flow of the cave stream system so that the system response can be analyzed if there are pollutants entering the cave stream system.

The validation test above through flow characteristics, namely time to peak (Tp) and runoff volume, analyzes the relationship between water quality and flow discharge, water quality and rain, and tracer test. The faster the time to peak (Tp) and the higher runoff volume, the groundwater is more susceptible to pollution. The higher the level of elements with the increase in flow rate, the groundwater is increasingly vulnerable to pollution. Increasing the flow of groundwater flow is influenced by rainwater, so the relationship between water quality and rain is also in line with that. Tracer test is the most accurate validation method because tracer substances are deliberately entered into groundwater systems to determine the speed of travel time. The faster the travel time of tracer substances, the more vulnerable the groundwater will be to pollution [15].

\section{Results and Discussion}

The Jonggrangan formation is part of the Kulon Progo Mountains which has a morphology in the form of a dome that lies from the northeast to the southwest along $32 \mathrm{~km}$. This area was formed by the lifting process that occurred during the Pleistocene [16]. The Jonggrangan formation is located at the top of the Kulon Progo Mountains as shown in Figure 1. The Jonggrangan formation is composed of conglomerate rocks, marl tuff, sandstones with lignite inserts, layered limestones, and coral limestones. This formation is right below the Sentolo formation, which means that the Jonggrangan formation is older than the Sentolo Formation. The thickness of the Jonggrangan formation is estimated to be around 250 meters [17]. 


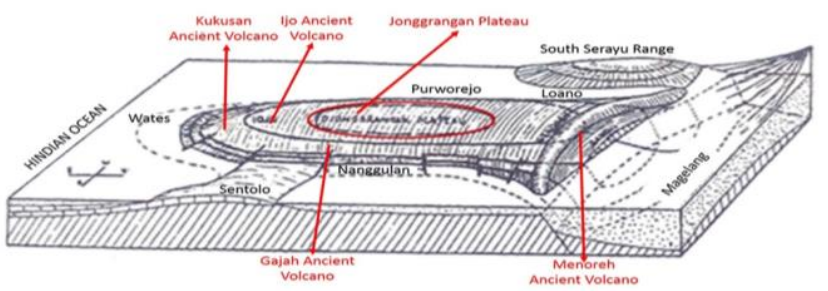

Fig 1. The Kulonprogo Dome Scheme [14,18]

\subsection{Cave Mapping}

Semar Cave is located at the coordinates of $403800 \mathrm{mT}$ and $9143697 \mathrm{mU}$. This cave entrance is located at the base of a doline with a mouth width of 6.9 meters. There is an underground river in this cave. The underground river leads to a sump or cavity that cannot be traced again because it is full of water. The tracer test using uranine substance in this research location was carried out. Based on the results of mapping, it was identified that the total length of Semar Cave cavities up to the sump reached 158.2 meters (Figure 2). The obtained ornaments found in Semar Cave included stalactite, stalagmite, drapery, column, and micro gourdam.

Semar Cave was mapped with a top-to-bottom survey system. In this system, the direction of data collection was from outside to inside of the cave. Mapping started at the point in front of Semar Cave entrance, then proceeded into the cave. The cave mapping survey method used was the forward method because the shooter position was always behind the stationer. After reading the measurement tools (leica disto and clinometer) and reporting the results of reading the descriptor, the shooter moved to the stationer position in front of it. After the station point was occupied by the shooter, the stationer moved to the front to determine the next station. The results of the Semar Cave mapping in the form of a 3D model are presented in Figure 2 using compass program, whereas the morphometric data are presented in Table 1. The Semar cave cavities dominantly directed to the northwest and northeast as shown in the rose diagram in Figure 3.

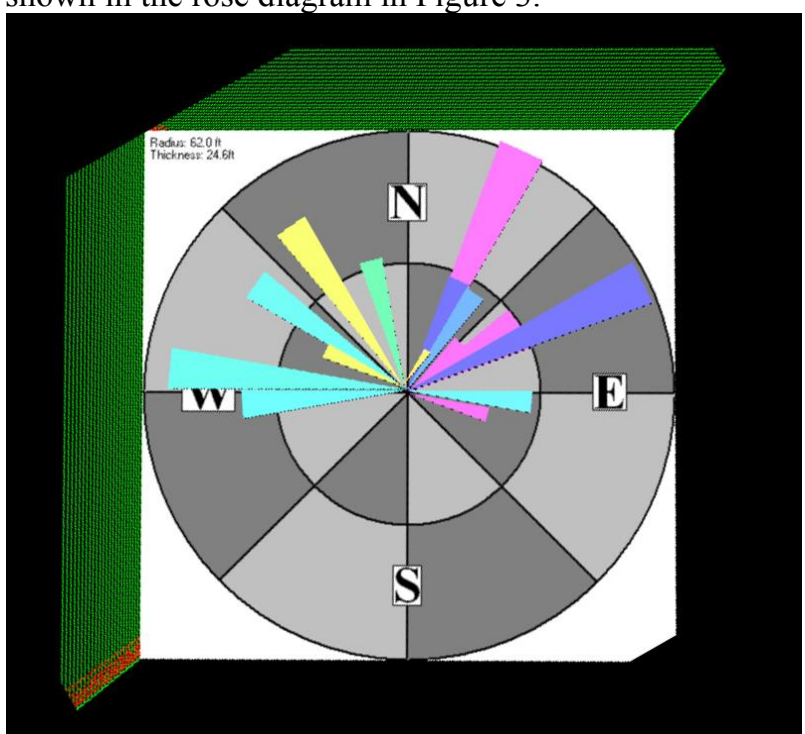

Fig. 3. Rose Diagram of Semar Cave Cavities
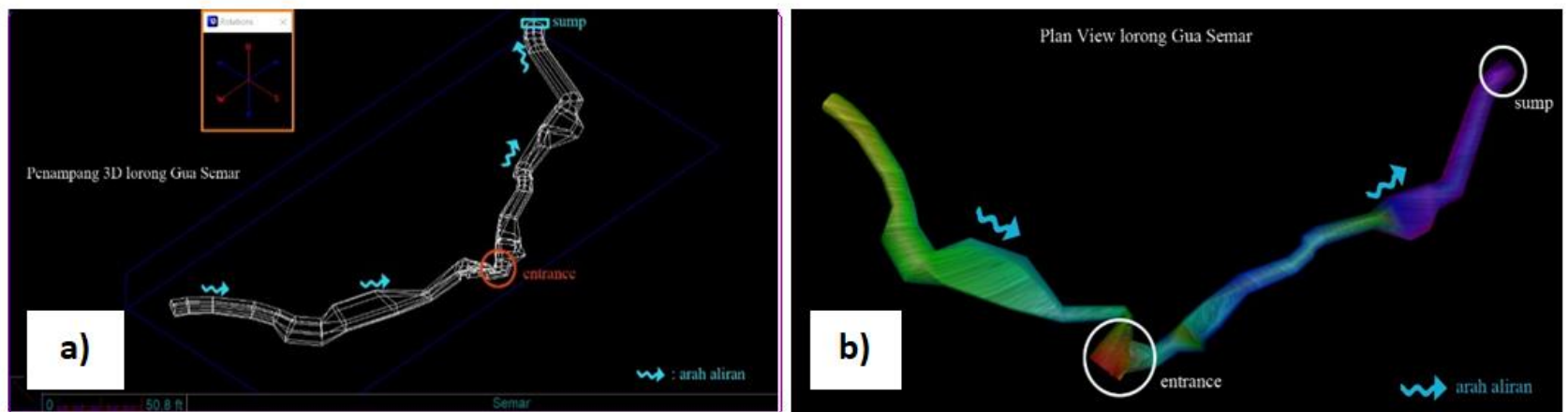

Fig 2. a) the 3D model of Semar Cave cavities b) the plan view of Semar Cave cavities 
Table 1. The Measurement Results of Characteristics of Semar Cave Cavities

\begin{tabular}{|c|c|c|c|c|c|c|c|c|}
\hline from & to & length & compass & clino & left & up & down & right \\
\hline 0 & 0 & 0 & 0 & 0 & 4.300 & 5.800 & 0 & 2.600 \\
\hline 0 & 1 & 2.409 & 32 & -20 & 2.347 & 1.637 & 0 & 2.937 \\
\hline 1 & $\mathrm{a}$ & 8.233 & 22 & -35 & 1.110 & 1.155 & 0 & 1.697 \\
\hline $\mathrm{a}$ & $\mathrm{b}$ & 10.576 & 262 & 5 & 1.762 & 2.862 & 0 & 0.779 \\
\hline $\mathrm{b}$ & $\mathrm{c}$ & 14.787 & 277 & 4 & 0.978 & 1.321 & 0 & 1.529 \\
\hline $\mathrm{c}$ & $\mathrm{d}$ & 11.681 & 305 & 0 & 0.415 & 1.876 & 0 & 7.308 \\
\hline $\mathrm{d}$ & $\mathrm{e}$ & 8.083 & 349 & 5 & 3.585 & 2.029 & 0 & 2.648 \\
\hline $\mathrm{e}$ & $\mathrm{f}$ & 11.825 & 322 & 4 & 1.081 & 1.825 & 0 & 2.243 \\
\hline $\mathrm{f}$ & $\mathrm{g}$ & 5.065 & 300 & 0 & 1.081 & 1.825 & 0 & 2.243 \\
\hline 1 & 2 & 8.329 & 92 & -30 & 2.347 & 1.637 & 0 & 2.937 \\
\hline 2 & 3 & 4.206 & 31 & -3 & 1.622 & 1.128 & 0 & 1.597 \\
\hline 3 & 4 & 3.788 & 36 & -1 & 0.814 & 4.532 & 0 & 4.746 \\
\hline 4 & 5 & 8.170 & 63 & -1 & 0.601 & 1.956 & 0 & 3.991 \\
\hline 5 & 6 & 9.233 & 67 & 0.5 & 1.852 & 0.615 & 0 & 1.464 \\
\hline 6 & 7 & 3.638 & 35 & -2 & 1.456 & 1.293 & 0 & 1.445 \\
\hline 7 & 8 & 9.202 & 70 & -5 & 2.138 & 1.508 & 0 & 1.091 \\
\hline 8 & 9 & 9.074 & 52 & -5 & 1.242 & 4.779 & 0 & 1.157 \\
\hline 9 & 10 & 5.702 & 105 & -1 & 1.446 & 1.498 & 0 & 5.918 \\
\hline 10 & 11 & 18.833 & 21 & 0 & 2.262 & 1.745 & 0 & 2.205 \\
\hline 11 & 12 & 5.049 & 49 & -4 & 1.673 & 1.421 & 0 & 1.955 \\
\hline
\end{tabular}

Source: Cave mapping (2018)

\subsection{Tracer Test}

The tool used to detect the tracer substance in this research was a fluorometer. This fluorometer was installed in Kiskendo Cave as a location which was estimated at which the tracer substance would appear that had previously been poured with uranine in Semar Cave sump. The results of this tracer test were in the form of a breakthrough curve showing the relationship between the concentration of tracer substance and the time recorded by the fluorometer. The breakthrough curve as the results of this test could reflect the characteristics of groundwater flow and underground river structure which were inaccessible [19]. This breakthrough curve could also be synthesized as a model of a karst aquifer [18,20].

It is predicted that Kiskendo Cave was previously connected to the flow from Semar Cave. Based on the results of the test, it was identified that the underground river of Kiskendo Cave was supplied from that of Semar Cave. Semar Cave was at coordinates of $403800 \mathrm{mT}$ and $9143697 \mathrm{mU}$, the cave mouth was at the bottom of a closed basin. Kiskendo Cave was at coordinates of $404249 \mathrm{mT}$ and $9143492 \mathrm{mU}$, with a flat distance from Semar Cave approximately 400 meters.
The solution of tracer substance (uranine) poured into the sump in Semar Cave began to be detected visually in Kiskendo Cave approximately 5 hours with a flat distance of about 400 meters. The measured discharge when pouring the tracer substance in Semar Cave cavities was 9.4 liters/second. Meanwhile, the flow discharge from Semar Cave to Kiskendo Cave from the breakthrough curve was 18.0 liters/second.

The uranine injection in Semar Cave was carried out on April 15, 2019 at 1:00 p.m. with a quantity of 80 grams. Based on the recording of the fluorometer installed in Kiskendo Cave, the peak uranine concentration was $138.05 \mathrm{ppb}$ on 15 April 2019 at 8:05 p.m. Time of first detection was 5 hours. The breakthrough curve showed 1 peak, indicating that the cavities from the injection point were single conduit connected to Kiskendo Cave. The type of cavities shows the magnitude of the role of allogenic river in the formation of cavities in the underground river system [6]. Based on the results of logger recording of the water level in Kiskendo Cave, the average discharge during the fluorometer installation time span was 125 liters/second. The breakthrough curve of Semar - Kiskendo Caves with coeff. of determination $\left(\mathrm{R}^{2}\right)$ is 0.976 is shown in Figure 4. 


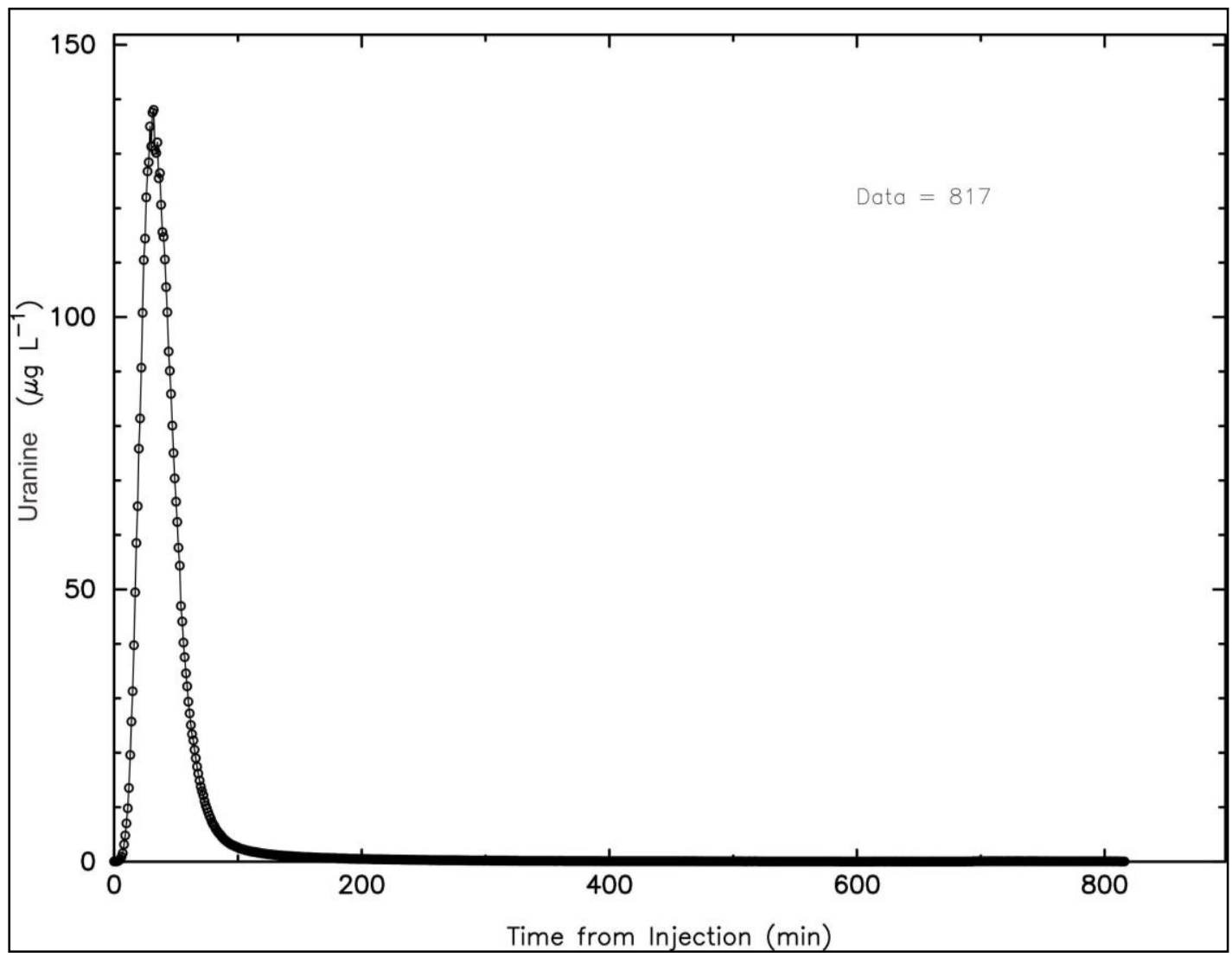

Fig. 4. The Breakthrough Curve Semar - Kiskendo Caves

\section{Conclusion}

The total cave cavities that could be mapped at Semar Cave were 158.2 meters, cave volume is $1220.6 \mathrm{~m} 3$, average diameter of cavities is $2.8 \mathrm{~m}$, wall area is 1899.8 $\mathrm{m} 2$. The end of the mapped cavities was in the form of a sump, or cavity with full of water. The results of the tracer test showed the connection between Semar Cave and the underground river in Kiskendo Cave. Interpretation of the Breakthrough curve shows the formation of a single conduit which is a sign of the dominant role of allogenic river in the formation of cavities.

This research is part of the first researcher's thesis at the Master Program on Planning and Management of Coastal Area and Watershed, Faculty of Geography, Gadjah Mada University, Indonesia. This research is funded by the research grant with the scheme of the 2019 Grants for Higher Education Basic Research (PDUPT), Universitas Gadjah Mada.

\section{References}

1. D. Ford dan P. Williams, Karst Geomorphology and Hydrology. West Sussex: John Wiley and sons, inc (2007)

2. E. Gilli, Karstology: Karst, Caves and Spring. London: CRC Press (2015)
3. S. Trudgill, Limestone Geomorphology. Hongkong: Longma (1985)

4. D. Drew and H. Hötzl, Karst Hydrogeology and Human Activities. Rotterdam: AA Balkema (1999)

5. S.B. Kusumayudha, Hidrogeologi Karst dan Geometri Fraktal Daerah Gunungsewu. Yogyakarta: Adicita Karya Nusa (2005)

6. A.N. Palmer, Cave Geology. USA: Allen Press (2007)

7. A. Cahyadi, E.S. Pratiwi, and H. Fatchurohman, Metode-metode Identifikasi Karakteristik Daerah Tangkapan Air Sungai Bawah Tanah dan Mataair Kawasan Karst: Suatu Tinjauan. dalam Marfai, M.A. and Widyastuti, M. 2013. Pengelolaan Lingkungan Zamrud Khatulistiwa. Yogyakarta: Pintal (2013)

8. A. Cahyadi, and R.F. Agniy, Analisis Breakthrough Curve Untuk Karakteristerisasi Pelorongan Di Sistem Sungai Bawah Tanah Pindul Kabupaten Gunungkidul. Proceeding of Pertemuan Ilmiah Tahunan Ke-1 Perhimpunan Ahli Airtanah Indonesia (PIT-PAAI). Bandung, 16 - 17 November 2016, 375 - 385 (2016)

9. I.A. Riyanto, A. Cahyadi, T.N. Adji, E. Haryono, M. Widyastuti, R.F. Agniy, W.A. Fathoni, N. Rahmawati, and H. Baskoro, Analisis Konektivitas dan Karakterisasi Pelorongan dengan Uji Perunutan pada Mataair Epikarst Sub-sistem Panggang, Kawasan Karst Gunungsewu. Proceeding of Pekan Ilmiah Tahunan Perhimpunan 
Ahli Airtanah Indonesia (PAAI) yang diselenggarakan di Hotel Aryaduta, Jakarta, $7-8$ November 2018 (2018)

10. R.F. Agniy, A. Cahyadi, and A. Nurkholis, Analisis Karakteristik Akuifer Karst Dengan Uji Perunutan Dan Pemetaan Gua. Proceeding of Kongres \& Pertemuan Ilmiah Tahunan ke-2 Perhimpunan Ahli Airtanah Indonesia (PIT-PAAI). Yogyakarta, 13 15 September 2017 (2017)

11. N. Goldscheider, J. Meiman, M. Pronk, and C. Smart, Tracer tests in karst hydrogeology and speleology, International Journal of Speleology, 37, 1: 27-40 (2008)

12. Drew D., Hotzl H. Karst Hydrogeology and Human Activities Impacts, Consequences, and Implications. Netherlands. A.A. Balkema (1999)

13. E.E. Laksmana, Stasiun Nol: Teknik-Teknik Pemetaan dan Survei Hidrologi Gua. Yogyakarta: Datagraff (2016)

14. R. Benischke, N. Goldsceider, and C. Smart, Tracer Techniques. dalam Goldsceider, N., dan Drew, D (eds). 2007. Methods in Karst Hydrogeology. London: Taylor \& Francis Group (2007)

15. M. Widyastuti, Kajian Kerentanan Airtanah Terhadap Pencemaran di Daerah Karst Gunung Sewu (Studi di Daerah Aliran Sungai Bawah Tanah Bribin Kabupaten Gunungkidul dan Wonogiri). Disertasi. Yogyakarta: Fakultas Geografi (2014)

16. R.W.V. Bemmelen, The Geology of Indonesia, The Hague: Goverment Printing Office (1949)

17. H. Hidayah, Potensi Mataair untuk Kebutuhan Air Minum Penduduk di Kawasan Karst Jonggrangan. Thesis. Yogyakarta: Faculty of Geography, Universitas Gadjah Mada (2007)

18. R.F. Agniy, T.N. Adji, A. Cahyadi, A. Nurkholis, and E. Haryono, Characterizing the Cavities of Anjani Cave in Jonggrangan Karst Area, Purworejo, Central Java, Indonesia, The Second International Conference in Environmental Resources Management in Global Region, Yogyakarta, Indonesia, 22-23 October 2018 (2018)

19. M.S. Field, ,A Review of Some Tracer-Test Design Equations for Tracer-Mass Estimation and SampleCollection Frequency. Environmental Geology, 43: 867-881 (2003)

20. M.S. Field, Tracer-Test Design for Losing StreamAquifer Systems, International Journal of Speleology, 35(1): 25-36 (2005) 